\title{
Miradas críticas sobre el teatro posdramático ${ }^{1}$
}

\section{Critical Views on Post-dramatic Theater}

\author{
Beatriz Trastoy \\ Facultad de Filosofía y Letras, Universidad de Buenos Aires. Argentina \\ btrastoy@hotmail.com
}

Resumen - Al analizar el teatro posdramático, tanto la crítica académica como la periodística muestran cierta incomodidad hermenéutica, la cual suele resolverse en el señalamiento de los distintos grados de lo real verificados en la escena, procedimiento que, aunque pertinente, tiende a funcionar como un límite interpretativo. Por ello, este artículo propone la teoría de la traducción como una posible clave de lectura a fin de superar o, al menos, de complementar esta limitación. A modo de ejemplo, se considera la puesta en escena de Los muertos (Ensayo sobre representaciones de la muerte en la Argentina) (2006) de Beatriz Catani y Mariano Pensotti, basada en el célebre relato de James Joyce.

Palabras clave: teatro posdramático, traducción, Joyce, Catani, Pensotti, crítica.

Abstract: When analyzing post-dramatic theater, the critique, both from the academy and the media, reveals a kind of hermeneutic uneasiness which is often resolved by pointing out different degrees of reality on stage. Although pertinent, this mechanism works as an interpretative limitation. This article intends to propose the translation theory as a possible key of reading in order to overcome or, at least, to complement that critical limitation. With this aim, the author considers the staging of Los muertos (Ensayo sobre representaciones de la muerte en la Argentina) (2006) by Beatriz Catani and Mariano Pensotti, based on «The dead», the welllknown James Joyce'short story.

Keywords: postdramatic theatre, translation, Joyce, Catani, Pensotti, criticism.

1 Una síntesis de este trabajo fue presentada en el VII International Conference on Latin American Theatre Today, Virginia Tech University, Department of Foreign Languages \& Literatures of the College of Liberal Arts \& Human Sciences (Blacksburg, Virginia, Estados Unidos), 26 al 29 de marzo de 2008. 
Escribir teatro es también traducir el lenguaje de las intuiciones, pulsiones, ideas, apariciones inesperadas, imágenes internas, etc., a un lenguaje que todavía no existe, pero, una vez terminada la pieza, creará todas las interrelaciones entre signos que constituyen lo que entendemos por lenguaje.

Rafael Spregelburd ${ }^{2}$

A partir de los años 60 se verifica en Occidente una nueva tendencia escénica que suele denominarse "posrepresentacional», "posantropocéntrica», "posorgánica» o, más generalizadamente, "posdramática», siguiendo a Hans-Thies Lehmann (2002). Al poner en crisis la noción de representación como instancia fundacional del teatro, dicha tendencia propone nuevos paradigmas perceptivos que plantean desafíos teóricos y prácticos al ejercicio profesional de la crítica periodística y académica. Si se acepta la idea de que el teatro tradicional — digamos «dramático»- en la medida en que imita, duplica, crea la realidad, genera o (directamente) impone las leyes que ordenan los modelos de su propia lectura, cabe, entonces, preguntarse si el llamado "teatro posdramático", caracterizado por la impugnación de las categorías dramáticas tradicionales, tales como desarrollo lógico de la historia, espacio, tiempo, personaje, entre otras, evidencia una similar autorregulación interpretativa pues, al borrar las fronteras entre lo real y lo ficcional, ya no se postula como doble o espejo de otra cosa, sino como equivalente de la vida misma. Ciertamente, las variadas formas de la escritura autorreferencial («docudramas», "autoperformances», "autoficciones» y los más recientes e imprecisamente denominados «biodramas»), constituyen no sólo el principio constructivo de estas nuevas formas escénicas, su principal artificio, sino también la matriz semántica que modula un aspecto fundamental de su programa interpretativo. No obstante, la crítica académica y periodística que intenta abordar las expresiones posdramáticas muestra cierta incomodidad hermenéutica que, con frecuencia, se resuelve en el módico señalamiento de los distintos grados de lo real que se verifican en la escena. Si bien atinado y pertinente, este reconocimiento de lo real tiende a funcionar como un límite interpretativo, en la medida en que parece provocar la suspensión de las habituales estrategias argumentativas y del consiguiente juicio evaluativo, que sustentan la especificidad discursiva de la crítica teatral.

Intento proponer aquí una posible clave de lectura capaz de complementar o, al menos, de superar esta limitación. Para ello, consideraré la puesta en escena de Los muertos (Ensayo sobre representaciones de la muerte en la Argentina), escrita y dirigida por Beatriz Catani y Mariano Pensotti, estrenada en 2005, en el Hebbel am Ufer de Berlín, y luego presentada en Buenos Aires en 2006 y 2007. Tal elección es sólo a modo de ejemplo, ya que el teatro posdramático que comienza a desarrollarse en la Argentina en los años 60 y se retoma, intensificado, a partir de la reinstauración del sistema democrático, es difícilmente reductible a un modelo único, pues ha presentado y sigue presentando numerosas variantes en el campo de la creación escénica.

2 En <http://www.autores.org.ar/spre/Creacion/obras/heptalogia/notas.htm>. 


\section{CUERPOS PRESENTES, CUERPOS AUSENTES}

Básicamente, la puesta en escena de Los muertos (Ensayo sobre representaciones de la muerte en la Argentina) se estructura en torno de dos monólogos desarrollados a partir de secuencias alternadas en áreas escénicas diferentes, que no interfieren entre sí: por un lado, el monólogo del actor Alfredo Martín quien, dirigiéndose al público, se presenta con su verdadero nombre y cuenta un grave accidente automovilístico que sufriera su hermano. Luego, explica al público que narró este evento familiar ya que los directores, cuyos nombres reales no se mencionan en ningún momento del espectáculo, le pidieron que hablara de una experiencia reciente con la muerte. De inmediato, comenta que intentará reconstruir - también por pedido de los directores- la puesta en escena de Los muertos, adaptada del cuento homónimo de James Joyce, supuesto espectáculo del que participara en un rol ínfimo varias décadas atrás, en la provincia de Corrientes, de donde dice ser oriundo. Por otro lado, a partir de las imágenes que se visualizan en un televisor (monumentos fúnebres de cementerios de Buenos Aires, artistas argentinos representando escenas cinematográficas de muerte, entrevistas a sepultureros y a técnicos teatrales), el actor Matías Vértiz, a cargo del otro monólogo, reflexiona acerca de las múltiples analogías que vinculan teatro y cementerio: la teatralidad que ambos generan, la concepción y el funcionamiento de los cuerpos en cada uno de ellos, las equivalencias estéticas entre escenografía escénica y arquitectura funeraria, las fuentes teóricas utilizadas como punto de partida de dicha reflexión (un texto de Habermas) y la cantidad y causa de muertes reales ocurridas durante la preparación del espectáculo que se desarrolla ante el público. A su vez, con tono neutro, opinando a veces, seleccionando, sintetizando, agregando datos, mostrando sus dificultades en encontrar las equivalencias lingüísticas, un traductor (Nikolaus Kirstein) vuelca al alemán todos los comentarios de Vértiz y sólo algunos de los que corresponden a la reconstrucción escénica a cargo de Alfredo Martín. Entre ambos monólogos y, a su vez, entre escenario y platea, se despliega un complejo juego de múltiples mediaciones que conciernen tanto al nivel de la enunciación como al del enunciado, indisolublemente vinculadas entre sí.

En cuanto a la enunciación, Alfredo Martín narra una puesta en escena y, sólo eventualmente, «representa» a algunos de los principales personajes de la obra en cuestión, planteando así la oposición básica entre los modos escénicos de "presentación» y de «representación» (De Marinis, 1982). En efecto, a diferencia del más tradicional teatro de «representación» que «re»-produce en escena personas y acciones, remitiendo a otra cosa diferente de sí, el teatro de "presentación» —-del que los espectáculos de narración oral son algunas de sus muchas variantes, ya que en ellos no se ven cosas, ni acciones ni personajes, sino sólo el cuerpo del narrador en el que se inscriben los gestos, la voz los ritmos, los silencios (Trastoy, 2002) - privilegia el cuerpo del artista convertido en sujeto/objeto (ya no en personaje), cuyo trabajo se desenvuelve en el espacio y en el tiempo reales y, por lo tanto, acentúa la autorreferencialidad, es decir, el aspecto vinculado a su propia producción. Precisamente, Alfredo Martín no sólo pone el acento en el hecho mismo de su condición de actor de un espectáculo teatral a quien se le ha encomendado la labor escénica de «narrar»y no «representar» otro espectáculo teatral, sino también en el modo en que construyó el relato de la re-construcción de una puesta en escena, proceso que lo llevó a transitar — y a poner en escena, es decir, a «representarlos»— casi todos 
los roles vinculados al hecho teatral: investigador, historiador, autor, director, intérprete, crítico. En efecto, como «investigador» de un supuesto hecho escénico que lo tuvo como protagonista secundario (fue un mero figurante de la representación correntina), Alfredo Martín remite a las imprevistas, fragmentarias, selectivas, poco confiables traducciones que operan las distintas formas de la memoria: la suya; la del anciano asistente de dirección que lo ayuda a reconstruir el espectáculo con sus viejas cartas y su peculiar memoria senil, ya que recuerda que el arbolito de Navidad era un espinillo y cuáles eran los ingredientes del ponche. No obstante, confunde u olvida otros aspectos centrales; el valor documental que brindan las fotografías y las cassettes grabadas para la radio provincial; la memoria materializada en los objetos escenográficos también supuestamente recuperados y reciclados para la ocasión. Como «historiador", Martín realiza su propia mediación, en tanto actualiza e interpreta esos documentos escritos, gráficos y orales y selecciona los materiales que le permitirán reconstruir la obra, convirtiéndose así en una suerte de "autor-director-intérprete». Como "crítico», se pregunta sobre el propósito de los responsables al encarar un proyecto escénico de reconstrucción como el que le encomendaron, evalúa el resultado (para él decepcionante) de lo finalmente reconstruido y concluye afirmando que nunca se tiene aquello que se quiere recuperar.

A su vez, la primera y la última de las nueve secuencias que componen el monólogo de Matías Vértiz también contienen referencias al contexto social en el que se insertaron las condiciones de producción del espectáculo; esto es, se alude a algunos informes estadísticos surgidos a partir de la investigación en instituciones públicas, hospitales y cárceles; se enuncian datos acerca de la cantidad y causa de las muertes producidas en el país durante la elaboración de la obra: las provocadas por accidentes laborales, de tránsito o catástrofes naturales; el número y el análisis porcentual de las edades de las víctimas del denominado «gatillo fácil» de la policía; las personalidades del mundo del espectáculo nacional fallecidas en ese período. Asimismo, se comentan datos referidos a los conflictos que se dan en ciertas comunidades por posesión de tierra en cementerios; a la cada vez más habitual práctica de venta telefónica de parcelas familiares en necrópolis privadas; a los numerosos cementerios virtuales interactivos para humanos y mascotas que, desde el comienzos del nuevo siglo, ofrece la Internet; a las nuevas propuestas empresariales orientadas a resolver el destino final de los restos de los restos, tales como la solemne dispersión de las cenizas realizada desde un barco, la posibilidad de hacerlas girar eternamente alrededor de la Tierra en un nave espacial, especialmente diseñada para tal efecto o, inclusive, la posibilidad de depositar algunos gramos de ellas en la Luna, creando así una especie de camposanto selenita, que, en un futuro no muy lejano, podría ser visitado regularmente por los deudos.

Las otras secuencias del texto enunciado por Vértiz se construyen a modo de quasimonólogo o quasi-diálogo, con las imágenes de video que se ven en el televisor — sobre las que no se puede afirmar con precisión si ilustran el discurso verbal del actor o si son ilustradas por él- y con el traductor, de quien no espera una réplica a su palabras, sino la versión al alemán de lo que enuncia. Semánticamente, estas secuencias reflexionan sobre los distintos lenguajes expresivos que establecen paralelismos entre cementerios y teatro. En ellas están implícitas las preguntas acerca de qué se ve y qué vemos en la escenografía/arquitectura de cada uno de ellos, en tanto puestas en escena de que hacen presentes los cuerpos ausentes. En las imágenes del video se observan los monumentos funerarios que prologan más allá de la vida las diferencias sociales entre ricos y po- 
bres, como así también las tumbas de los artistas, cuyas imágenes retoman momentos de esplendor en el ejercicio de su arte. Se repiensa el gusto de los actores por representar escenas de muerte y se detiene en el cine argentino, más precisamente en una escena de La Mary (1974), dirigida por Daniel Tinayre, donde la protagonista (Susana Giménez) asesina a su marido, interpretado por Carlos Monzón, ex campeón mundial de boxeo, en la vida real, quien, años más tarde, asesinaría a golpes a su esposa. Indirectamente se reflexiona a través de entrevistas a especialistas que se reproducen en el video, sobre las tareas de los trabajadores de cementerios (que, al inhumarlos, ocultan los cuerpos) y de su equivalente, los técnicos teatrales (iluminadores, sonidistas, etc.) que hacen ver y oír a los cuerpos en escena. Su presencia - la de sepulturero y técnico teatral- no es visible o no es visualizada por los asistentes a las respectivas ceremonias. En las entrevistas, ambos explican cuándo usan guantes (por higiene y por seguridad, respectivamente), cómo llegaron a desempeñar esas funciones, cómo se relacionan con el público de cada lugar, cómo se emocionan frente al dolor y frente a un estreno. Vértiz explicita que cierto texto de Habermas ha sido el marco teórico de su propio discurso, y, en última instancia, del proyecto escénico de Catani-Pensotti, y lo desplaza al plano social local, al presentar la Argentina como un país de muertes en tierras lejanas y de cuerpos ausentes (Mariano Moreno, Jorge Luis Borges, Eva Perón, Carlos Gardel, los desaparecidos durante la última dictadura militar).

Si la autenticidad de los datos ofrecidos en estas secuencias monologales de Vértiz pueden corroborarse por las imágenes de video que se visualizan en el televisor y/o por medio de una simple y accesible investigación documental, la veracidad de las referencias autobiográficas de Alfredo Martín (el accidente de su hermano, su ejercicio de memoria en el proceso de investigación y la resultante reconstrucción escénica de la representación correntina de la adaptación del cuento de Joyce, las indicaciones dadas por los responsables del espectáculo) resultan, en cambio, de imposible comprobación empírica. Ciertamente, determinar el carácter real o ficcional de los relatos autobiográficos del actor o, planteado de otro modo, determinar cuánto de real y/o cuánto de ficcional hay en esos relatos resulta difícil, sino imposible. El teatro posdramático nos enfrenta así a la cuestión de la indecidibildiad de la relación entre autenticidad e invención, entre ficción y realidad, propios de la práctica y en la teoría de la escritura del yo, aunque no privativos de ella. De hecho, establecer el estatuto de la ficción en sí misma resulta una tarea sumamente compleja. No obstante, más allá de las variadas perspectivas aplicables al tema, siguiendo un tradicional criterio diferenciador que parece convenir a la problemática autobiográfica, puede decirse que todo texto referencial se deja constatar con la realidad, mientras que, por el contrario, el texto ficcional no admite tal constatación y, por lo tanto, se define por la diferencia que media entre lo referido y los hechos a los cuales se refiere, diferencia que no debe ser corregida, sino solamente interpretada o criticada. Los materiales que intervienen en el relato autobiográfico, aunque se ajustaran estrictamente a la realidad vivencial del sujeto, «sólo en apariencia» serían verificables. Dado que la ficcionalidad se asocia comúnmente a la invención, cabría asimismo intentar definir cuál es su estatuto en el relato autobiográfico. Siguiendo los principios de la retórica clásica, Jean Marc Blanchard duda acerca de la posibilidad de que exista narratio sin inventio y señala que ésta consiste en: 
la elaboración de lugares comunes o topoi los cuales ayudarán al hablante a formular sus pensamientos: la secuencia cur? quomodo? quando? constituye un conjunto de referencias de marco a emplear, gracias a la cual emergerá un discurso de la mera jerarquización de las respuestas (1978: 657).

En efecto, al seleccionar y exponer las vivencias personales con una cierta disposición basada en un proceso de focalización, desfocalización y refocalización de los hechos, proceso que da por resultado un determinado y significativo montaje de la propia historia, el autobiógrafo se apropia de manera consciente de los procedimientos y técnicas empleados en los discursos habitualmente considerados ficcionales, transformando en artefacto los sucesos reales de orden empírico. El condicionamiento que imponen las convenciones literarias y culturales hace que todo relato sea, en última instancia, una construcción ficcional. Por lo tanto, la narración autobiográfica no puede ya asociarse ni a la idea de una «verdad» en relación con los hechos referidos, ni tampoco a la idea de la invención en sentido estricto. Por ello, Renza (1977) afirma, atinadamente, que la autobiografía no sólo no es ni ficticia ni no ficticia, sino ni siquiera una mezcla de ambas: es, por el contrario, un único y autodefinido modo de autorrepresentación. En este espacio ambivalente entre enunciado ficcional y enunciado verdadero, en este espacio de cuestionamiento de la verdad como producto de la construcción lingüística, adquiere peculiar interés el concepto de "autoficción», acuñado por Serge Doubrovsky en su Fils (1977). Se trata de una modalidad de la escritura del «yo» basada habitualmente tanto en la identidad onomástica entre autor, narrador y protagonista, como en la declaración de ficcionalidad realizada por medio de marcas paratextuales (subtítulo que indica el género «novela», dedicatorias, prólogos, aclaración sobre el carácter puramente casual de las semejanzas con personajes y hechos reales). En ciertos textos se recurre a la ausencia del nombre propio, a un pseudónimo o a una inicial, si bien en todos los casos deben existir vinculaciones más o menos estrechas entre éstos y el nombre del autor; asimismo, suele emplearse la heteronimia entendida como multiplicación o diversificación del yo autor/ narrador. Sin que se confunda con el relato en clave o con la novela en primera persona, la autoficción, que también puede escribirse en tercera persona, ficcionaliza la experiencia de vida, poniendo el acento en la invención de una personalidad. Por otra parte, mientras que la autobiografía no puede reducirse a la supuesta objetividad atribuida a los discursos referidos a lo real, a lo histórico, a lo clínico, a lo biográfico, la autoficción no puede ceñirse a la sinceridad u objetividad: integra la ficción y la confusión que proviene del inconsciente. La autobiografía pide ser creída, a partir del pacto entre emisor y receptor teorizado largamente por Lejeune (1973); la autoficción — siempre ambigua, siempre indecidible - pide, en cambio, ser y no ser creída al mismo tiempo, se postula como falsa y seria a la vez, sin dar al lector las claves necesarias para diferenciar los terrenos de la realidad y la ficción (Darrieusecq, 1996). Según Régine Robin:

Escritura, trabajo de duelo, a la vez de deconstrucción de la ilusión biográfica y de reconstrucción, elaboración de un lugar otro no aleatorio, lugar de verdad. Ésta sería la imposible tarea de ese objeto inasible que es la autoficción. Ni autobiografía ni biotexto ni museo portátil ni heteronimia radical, sino reelaboración de un rasgo que se ha transformado en palabra de verdad (1993:85). 
La presencia física de quien cuenta su vida en los medios masivos de comunicación o sobre un escenario complica la eficacia de la recepción del proyecto autobiográfico. Como en el caso del lector, el espectador común no suele tener la posibilidad de confrontar los datos que se dan como autobiográficos con otros documentos tenidos por verdaderos. Por cierto, las condiciones de enunciación propia de la televisión y del teatro, junto con el imaginario social, inciden en la validez del principio de verdad. De hecho, el testimonio de vida, narrado frente a las cámaras de televisión en un espacio considerado periodístico, resulta más creíble que si esa misma historia es relatada por la misma persona desde un escenario a los espectadores presentes. Asimismo, es más fácil considerar auténtica la autobiografía contada por un individuo ajeno a la práctica escénica que la narrada por un actor o actriz, siempre asociados a la impostura que supone representar personajes teatrales. Sobre la escena, todo es (o parece) ficción.

El gesto autobiográfico/autoficcional del relato de Alfredo Martín y la documentada — digamos- «veracidad» de los comentarios de Matías Vértiz resignifican las consideraciones sobre los modos de enunciación — presentación/representación, realidad/ficciónpresentes en ambos monólogos, en tanto se articulan con las complejas mediaciones que atañen al nivel del enunciado. En efecto, son ampliamente conocidas las marcas autobiográficas joyceanas presentes en «Los muertos»: al igual que Gretta Conroy, Nora Barnacle, la esposa de Joyce, era oriunda de Galway; como Gretta, Nora había sido amada por un joven que murió por ella; como Gabriel Conroy, Joyce sentía celos por ese amor de juventud de Nora; como Gabriel y Miss Ivors, los desacuerdos ideológicos con el nacionalismo irlandés frustraron una supuesta relación afectiva con una militante; como Gabriel, Joyce escribía en inglés y no en gáelico, lengua que consideraba artificialmente reivindicada. También deviene una fuerte referencia al carácter autobiográfico de la producción artística la transposición fílmica del cuento de Joyce, The dead (1987), dirigida por John Huston, a la que sin nombrarla se alude sutilmente en la obra de Cantani-Pensotti a través del reemplazo del recitado de «Donal Óg» — secuencia inexistente en el texto original de Joyce- por «De súbito, estalló la guerra» de la poeta, actriz y performer uruguaya Marosa Di Giorgio, cuya peculiar dicción es parodiada por Alfredo Martín en su declamación. Semanas antes de morir, John Huston dirigió The dead desde su silla ruedas con asistencia respiratoria; la película fue protagonizada por su hija Angélica, mientras que Tony, también hijo del director, fue el guionista. Precisamente, el desolado llanto del personaje de Gretta, en la decisiva escena final, es difícilmente separable del de la actriz-hija, a quien no podemos dejar de suponer consciente de que no sólo estaba participando de la última película de su padre, sino asistiendo a los últimos momentos de su vida.

\section{TRADUCIR/PONER EN ESCENA}

Resulta casi una obviedad afirmar que ambos monólogos tematizan, a través de la analogía entre teatro y cementerio, las distintas instancias de la creación teatral. Según Cornago:

Los cementerios y los teatros consisten en la puesta en escena de unas ausencias, que únicamente se pueden hacer presentes a través de su no-estar y de eso nos hablan las escenografías teatrales y las presentaciones la pie de las lápidas (2007: 220). 
Por cierto, al hablar del tiempo, de la muerte, de los cuerpos ausentes y presentes, de la memoria, de las representaciones, de las reconstrucciones, de lo público, de lo privado, de lo social y de lo individual se habla — de manera más o menos directa- de teatro, de sus valores, de sus funciones, sobre su estatuto ficcional, de su capacidad de significar y de comunicar. Si esto es así, ¿qué sentido, qué utilidad puede tener, entonces, el ejercicio crítico acerca de un teatro que, aparentemente, se autocritica al reflexionar sobre su propia problemática? ¿Qué más puede decirse, entonces, de un teatro que sólo parece pensarse y hablar de sí mismo? Para intentar salir de la inmovilidad que suponen tales cuestionamientos frente al teatro contemporáneo (y al arte en general) deberíamos empezar por preguntarnos si es cierto que este teatro «sólo" habla de teatro y, si no es así, de qué habla entonces y cómo analizar ese discurso.

Siempre siguiendo con nuestro ejemplo, en el caso concreto de Los muertos (Ensayo... de Catani-Pensotti, la presencia escénica del traductor resulta lingüísticamente tan innecesaria en Buenos Aires, como en ocasión de su estreno en Berlín, ya que las opciones para acercar un texto a quienes no conocen la lengua en la que éste se enuncia pueden ser otras, como el subtitulado, la entrega del texto parcial o completo a los espectadores, la síntesis argumental en el programa de mano, etc. La traducción al alemán en el escenario mismo fue seriamente objetada, especialmente por los realizadores locales, ya que se la consideró una concesión estética destinada a lograr su presentación en ámbitos internacionales. Desde mi punto de vista, por el contrario, la presencia escénica del intérprete («intérprete» en su doble acepción de «traductor» y «actor»), como así también la modalidad de su interacción con los otros dos actores, encubre y, al mismo tiempo, devela una de las posibles claves de lectura. Esto es, la traducción definida en sentido amplio - como traslación, adaptación, paráfrasis, comentario, parodia, reescritura, transformación, apropiación, cita, mediación - regula al menos una de las posibles interpretaciones del espectáculo.

Recién a mediados del siglo XIX comienza a cristalizarse la noción de puesta en escena como lectura, como «interpretación» en sentido amplio, es decir, como "traducción» en signos escénicos por parte de sus diferentes realizadores (actores, escenógrafos, iluminadores, maquilladores, vestuaristas, etc.), orientados y coordinados por el director, ya que, durante siglos, el trabajo escénico se entendió como fiel reproducción, como mera ilustración — casi prescindible - del texto dramático, sin dejar ningún margen a la creatividad productiva e interpretativa de realizadores y espectadores. Del mismo modo, durante mucho tiempo, la práctica de la traducción se consideró una tarea inefable, misteriosa o simplemente mecánica, ya que su valoración estaba casi exclusivamente ligada al concepto de fidelidad y se dejaban a un lado no sólo las características del universo discursivo de los textos (las particularidades sintácticas, semánticas y pragmáticas entre escritos científicos, comerciales, políticos o inclusive filosóficos, cuyas traducciones se pretenden más fieles al significado que al significante, y aquellos textos literarios o artísticos en general, en los que prevalece lo estético y exigen otros saberes y una mayor carga de subjetiva por parte del traductor), sino también las características de los universos culturales de las lenguas de origen y de llegada. No es casual, entonces, que la traducción, entendida como conocimiento autónomo, y el teatro posdramático, con su impugnación de la noción de drama y, por consiguiente de puesta en escena, comenzaran a teorizarse casi contemporáneamente a fines de los años 70, ya que entre ellos es posible establecer analogías, por demás evidentes, en la medida en que comparten ciertos cuestionamientos y problemáticas comunes. 
Traducibilidad y teatralidad son conceptos tan problemáticos como axiales en el ejercicio de la traducción y de la puesta en escena. Del mismo modo en que un traductor se pregunta si todo es traducible, qué se pierde, qué se gana, qué se modifica, qué permanece, el realizador teatral se pregunta qué tipo de textos es posible llevar al escenario, es decir, si cualquier texto dramático o no-dramático previo (si lo hay) o bien un azaroso guión surgido durante los ejercicios de improvisación con los actores pueden traducirse en signos escénicos.

Todo traductor traduce por una necesidad personal, por un deseo de otro texto, de decir lo que aún no sea ha dicho en su lengua o aún no se ha dicho de ese modo preciso en esa lengua o en su propia obra (Sergio Waisman en VV. AA., 2006), un deseo, en última instancia, de apropiación, de reescritura del texto (Gómez Ramos, 2000), un deseo de ampliar el horizonte de su propia lengua (Ricoeur, 2005). Por su parte, el director que elige cierto texto dramático y lo pone en escena con un determinado criterio estéticoideológico; el actor que encara un personaje de una cierta manera; el escenógrafo que construye el espacio escénico de tal o cual modo, responden a una similar necesidad de llenar en términos teatrales un vacío individual y socio-cultural que sienten intransferiblemente propio.

La compleja y discutida (siempre discutible) relación de dependencia/fidelidad del texto traducido con respecto al texto original, ¿es aplicable a la relación director-actor? ¿Al deseo de quién responde - supuestamente- la adaptación de la puesta colectiva correntina al unipersonal de Alfredo Martín? ¿Al propio, en tanto actor que decide participar de un proyecto conjunto, o al de los directores, responsables de la dramaturgia, tal como él mismo lo señala durante el espectáculo? ¿Cuál es el grado de dependencia máxima o mínima exigible (esto es, admisible, adaptable, traducible) de la creación del actor - y del resto de los realizadores escénicos-con respecto a la creación del director y, a su vez, la de éstos con respecto al autor del texto previo, si lo hubiera? La insatisfacción de Alberto Martín ante el resultado de su tarea ¿se debe a la evaluación de su propia tarea o la imposición de realizarlo, cumpliendo así con el deseo de "otro" por "otro" texto? ¿Qué horizontes se amplían para cada uno de ellos y para el teatro en este juego de traducciones múltiples? Los muertos (Ensayo... reflexiona así no sólo sobre los más evidentes borramientos de límites entre realidad y ficción, entre teatro y las distintas formas de lo no-teatral, sino también sobre los hábiles límites de la individualidad creativa en el colectivo de deseos de toda puesta en escena.

La traducción no es sólo el pasaje de una lengua de otra, sino, fundamentalmente, una operación intercultural en la que se adaptan sistemas sígnicos diferentes; es una forma de reflexionar sobre lo propio y sobre lo ajeno; un intento de comprendernos y de comprender a los otros. El «traductor [es] el que tiene que establecer dos modelos - uno con el interlocutor de partida y otro con el final-y hacerlos compatibles entre sí lógica y culturalmente en su oferta informativa (en la traslación)» (Reiss y Vermeer, 1996: 55). Las actitudes hacia la cultura que se pueden asumir en la operación traductiva son, según Pavis (1991), tres: en primer lugar, acentuar la diferencia cultural, evitando la adaptación de ideologemas y de conceptos filosóficos de la cultura fuente a la de llegada. Con este afán de fidelidad se corre el riesgo de volver incomprensible la cultura de partida y, por lo tanto, de dirigir el texto traducido a lectores especializados. De manera inversa, se puede optar por acercar ambas culturas, atenuando o disimulando al máximo sus diferencias. El riesgo resultante de esta posición complaciente que vuelve el texto demasiado familiar 
sería el de no permitir comprender su origen cultural-temporal. Una tercera actitud es la de intentar alcanzar un equilibrio aceptable entre diferencias y similitudes, que en el teatro pueden lograrse mediante distintos recursos dramatúrgicos y/o escénicos. Al respecto, Catani-Pensotti reflexionan en Los muertos (Ensayo... acerca de esta problemática de la traducción y de la adaptación en su doble aspecto, como transformación de un género a otro y como adecuación cultural. Desde el punto de vista lingüístico, el cuento de Joyce tematiza, entre otras muchas cosas, el conflicto de las lenguas nacionales (Gabriel Conroy, en tanto irlandés, es acusado de pro-británico por negarse a escribir en gaélico y colaborar en un diario inglés) como proyección del conflicto político-cultural más amplio y profundo entre Irlanda del Norte e Inglaterra. La vida del propio Joyce estuvo atravesada por esta confrontación, ya que defendió la lengua de su tierra irlandesa sólo después de radicarse en el exterior, más exactamente en Trieste, por ese entonces territorio irredento en disputa entre Italia y Austria, es decir, entre dos lenguas, entre dos culturas. En la obra de Catani-Pensotti, el texto de Joyce es (implícitamente) traducido del inglés al castellano, para luego ser (supuestamente) adaptado al teatro, adaptación, esta última, que, a su vez, se adapta no sólo - y otra vez- a la forma narrativa (el relato de Alfredo Martín como reconstrucción), sino también a la realidad local y cultural argentina en general y regional, dada la supuesta localización mesopotámica de la representación. En efecto, no son valses los que se bailan en la fiesta correntina, sino una galopera paraguaya más cercana a los ritmos musicales del litoral argentino y no es tampoco «Arrayed for the Bridal», con música de Bellini y letra de George Linley, lo que entona emocionada Julia, la tía de Gabriel, sino el chamamé "Merceditas», con letra y música de Ramón Sixto Ríos. Si la danza paraguaya refuerza el aspecto localista, el chamamé, a su vez, intensifica semánticamente no sólo el conflicto amoroso que atraviesa el relato de Joyce y sus adaptaciones teatrales y cinematográficas, sino también el gesto autobiográfico común al texto original y a sus traducciones/adaptaciones reales y/o ficticias. De hecho, «Merceditas» habla de la verdadera historia de amor de su autor por Mercedes Strickler Khalov, hija de inmigrantes alemanes afincados en Argentina, quien dos veces rechazó su propuesta de casamiento, historia que remite, indirectamente, al frustrado y trágico amor de Michael Furey por Gretta en el cuento de Joyce y a sus antes señaladas reverberaciones autobiográficas. Por otra parte, el recitado de "Donal Óg», poema irlandés anónimo del siglo VIII, en versión inglesa de Lady Gregory (también originaria del condado de Galway como Nora Barnacle y como su equivalente ficcionalizado, Gretta Conroy), introducido en la película por el guión de Tony Huston, texto que habla de promesas traicionadas, es reemplazado en la obra de Catani-Pensotti por el poema de Marosa di Giorgio, que conjuga la teatralidad de los juegos infantiles y la guerra, el más siniestro de los juegos de los adultos. Todos estos acercamiento a la cultura local borran (sin reemplazar) la problemática política anglo-irlandesa, pero refuerzan el semantismo autobiográfico axial del cuento y de la obra que nos ocupa. La cita indirecta a la película -el poema irlandés introducido por el guionista inexistente en el cuento- apela, en cambio, a un espectador conocedor de cine y de poesía contemporánea. Por otra parte, en la reconstrucción de Alfredo Martín no se reproduce la fiesta de Epifanía que reúne a parientes y amigos de Gabriel (festividad sin tradición social en nuestro medio), sino nuestra más familiar Navidad. En este caso, si bien acerca y facilita la comprensión del festejo, se pierde - y éste es un punto clave en la problemática teoría de la traducciónlo fundamental de la historia narrada por Joyce: la experiencia epifánica existencial de 
Gabriel Conroy no sólo acerca del futuro familiar y de su rol de subrogado afectivo en la vida de su esposa, sino también acerca de sus limitaciones como hombre y como intelectual, que el cuento sutilmente destaca.

Los juegos de adecuaciones y de equivalencias centradas en la temporalidad, es decir, en la posibilidad de inscribir un texto lejano en el tiempo en la época actual, con el riesgo implícito de las distorsiones semánticas que puedan provocar los anacronismos resultantes, son decisiones retóricas clave en toda traducción y en las operaciones que le son concomitantes (adaptaciones, paráfrasis, parodias). Si, como señala Patricia Willson (en VV. AA: 2006) toda traducción es una suerte de instantánea que plasma el estado de la lengua en un momento determinado en una cultura determinada, podríamos decir que toda puesta en escena da testimonio de una cierta concepción estética en una específica circunstancia histórica. El guión de Tony Huston respetó tiempo y espacio y redujo al mínimo la distancia cultural que establece la temporalidad entre cuento y película. El acercamiento del texto joyceano a la realidad cultural correntina hace desaparecer el conflicto lingüístico-cultural anglo-irlandés y, por ende, su coordenada temporal y lo asimila muy módicamente a la puja de intereses y rivalidad entre la capital del país y las provincias, que poco y nada tiene que ver con el sangriento enfrentamiento entre Irlanda del Norte y el Reino Unido a lo largo del siglo XX, que el cuento literaliza y, a la vez, metaforiza otros muchos desgarramientos personales y sociales. Si, como señala Gómez Ramos (2000), la traducción es una forma de cita, en tanto ésta, aspirando a repetir el texto con cierto grado de precisión, lo arranca, lo injerta y lo lleva a otro lugar distinto de su origen y — siguiendo a Eco (1988), nos permitimos agregar-de su temporalidad, es decir, de su tiempo histórico y escritural, ya que el tiempo de la cita fuerza a la confrontación de los respectivos universos de referencia entre dos textos. En el caso de la traducción/cita que opera el espectáculo de Catani-Pensotti con el relato de Joyce, la confrontación cultural entre centro y periferia (que implica siempre coordenadas temporales y espaciales) proyecta la relación Inglaterra/Irlanda hacia la relación países centrales/ Argentina y, a su vez, por una parte, Argentina/países limítrofes y, por otra, la más local Buenos Aires/interior. Quizás la condición «no-porteña» —otra vez lo autobiográfico, lo autoperformático- de gran parte de los realizadores del espectáculo haya sido determinante en este sentido.

La nueva traductología no deja de pensar en la visibilidad que el traductor puede o, eventualmente, debe asumir en su tarea, es decir, sobre la cantidad y calidad de las marcas de subjetividad que deben percibirse en el texto traducido. Algunos téoricos (Isnardi, 1998) consideran que ciertos errores, tanto ideológicos como literarios, que afectan la totalidad de la traducción se ponen en evidencia cuando el traductor se vuelve una presencia visible en la medida en que deja transparentar su propia ideología (haciendo leer cosas inexistentes en el original o, inversamente, omitiendo elementos que sí están en el texto), o que altera el estilo del autor, ya sea para lucir el propio o por carencia de sentido estético. Para Marías (1993), en cambio, la tradicionalmente deseada invisibilidad del traductor debe apoyarse en la noción de representación, implícita en la traducción, que finge ser el texto original y no su versión en otra lengua. Otras reflexiones sobre la nueva traductología (Guzmán, 2008) plantean que la ilusión de transparencia se vincula al carácter periférico de la práctica traductiva con respecto al texto de partida, en el marco de criterios modernos de producción cultural que valorizan al original por encima de cualquier forma de reproducción, de las que la traducción sería un ejemplo. Por otra 
parte, en el concreto entramado retórico de la reescritura del traductor, éste se visibiliza tanto al explicitar en el prólogo sus decisiones, sus perspectivas interpretativas (Graciela Marsico en VV.AA: 2006), como así también en las notas al pie. Sin embargo, mientras que en un trabajo académico las notas al pie forman parte del ineludible aparato erudito que legitima la autoridad y honestidad intelectual del autor, las del traductor, en cambio, vuelven cuestionable su tarea. «Lo que el traductor debe comprender es que, al intervenir al pie, lo que está haciendo es confesar una derrota, una derrota que no siempre debe adjudicarse a la inexperiencia, sino también, a veces, a la mala suerte» (Piro, 2004: 87). Un caso particular de visibilidad ostensible del traductor es la irrupción, entre paréntesis y en cursiva, de palabras en lengua extranjera o bien directamente en la lengua del texto original. Tales vocablos ajenos son otra forma de confesar el propio fracaso traductivo, pero también pueden ser interpretadas como una clave de sentido, como un intento de hacer leer dos o más lenguas en un solo texto, cuya identidad se disuelve inexorablemente (Gómez Ramos, 2000). El grado de dificultad de la traducción depende de la distancia temporal, cultural, de los puntos de vista, del sistema de referencia. Por ello, cuando tal dificultad se acentúa, la necesidad de superarla, de resolver los problemas presentados, lleva a una «conciencia técnica» (Steiner, 1980: 67). El video que ilustra o, quizás, inversamente, inspira los comentarios de Matías Vértiz; las observaciones sobre el proyecto de los directores, las dificultades encontradas y los resultados obtenidos en la recuperación/ construcción/puesta en escena realizados por Alfredo Martín; el cuasi-diálogo con el traductor; la traducción en sí misma constituyen señalamientos meta-actorales, metadramáticos y metateatrales equivalentes a las marcas de los traductores sobre su propio trabajo, a esos entrecomillados, cursivas o paréntesis que vuelven ajenos los vocablos y los cargan de nuevas intencionalidades. Son, en otras palabras, reflexiones tanto sobre la cantidad y calidad de las marcas de subjetividad que deben percibirse en el texto transmutado escénicamente, como sobre la forma en que las dudas y aclaraciones de los realizadores deben hacerse ostensibles al espectador como lo hacen las traducciones a través de notas al pie de página o de cambios gráficos que destacan los términos conflictivos.

Algunos traductores (Marcelo Cohen, en VV.AA., 2006) admiten el fastidio que les produce verse obligados a traducir a un autor a quien consideran inferior a sí mismos y, más aún, inferior al promedio de los escritores, fastidio que los lleva a cuestionar los criterios de selección de la industria editorial. Esta interesante problemática que pone en juego el narcisismo de los traductores, en tanto escritores, podría aplicarse a la relación entre la autoficción de Alfredo Martín y el texto de origen. El actor se muestra reticente, incómodo, ante la necesidad de reconstruir y narrar esa puesta en escena correntina, como así también duda sobre la importancia, la finalidad estética y el interés que pueda tener semejante tarea encomendada por los directores del espectáculo. La insatisfacción frente a la realización de la tarea de traslación/traducción encomendada y al resultado logrado no estaría vinculada a Joyce, indudablemente por encima de cualquier juicio de mediocridad escritural, sino más bien, por un lado, a la falta de datos concretos, de recuerdos fehacientes, de documentos confiables, en la que Martín parece preguntarse, junto a algunos teóricos de la traducción (Gómez Ramos, 2000), hasta qué punto la memoria - que es escritura, que es puesta en escena- realmente traduce. Por otro lado, estaría vinculada al hecho de verse obligado a reconstruir una puesta "menor», sin legitimación en el campo teatral nacional, en la que fue sólo un figurante sin el menor protagonismo. 
Por otro lado, si intentamos interpretar tal incomodidad en un plano más estrictamente metateatral, podríamos remitirla tanto a las habituales dificultades de los actores para transitar entre la interpretación y la narración oral, diferentes entre sí en sus técnicas, objetivos y alcances, como a la conciencia de la subestimación de la narración oral escénica como género, aún hoy considerado también «menor» y de alcances limitados por la crítica y la mayoría de los teatristas y espectadores en relación con el más tradicional teatro de representación. Si, como dijimos, la fastidiosa obligación de traducir aquello que se considera por debajo de la media aceptable del valor literario lleva a impugnar los criterios de selección de las editoriales, es decir, las asimetrías con los países desarrollados que imponen su canon estético y desplazan su campo intelectual, la promoción de la propia literatura en el exterior, los intercambios culturales, los subsidios para las traducciones, etc. (Gabriela Adamo en VV.AA.: 2006), el cuestionamiento acerca de cualquier traducción teatral - lingüística y escénica- supone revisar de manera similar las políticas culturales de gobierno, los criterios de programación aplicados en las salas oficiales y privadas, la selección de espectáculos para participar de festivales nacionales e internacionales.

\section{LA TRADUCCIÓN: UNA POSIBLE CLAVE HERMENÉUTICA}

Ahora bien, ¿cuál sería la eficacia de recurrir a un marco teórico ajeno a lo escénico o inclusive a lo estético en sí mismo, como en este caso la teoría de la traducción, a modo de clave interpretativa de un espectáculo considerado uno de los ejemplos del teatro posdramático, en el que precisamente la lengua ya no es más garantía de sentido?

Las nuevas orientaciones traductológicas consideran a la traducción como entrecruzamiento y fundación de prácticas discursivas, como un fenómeno socio-cultural y comunicativo, como hecho propiamente intercultural, como un problema semiótico que insiste en los deslizamientos de sentido, en el contraste lingüístico, en el juego de intertextualidades y transtextualidades, que discierne la otredad en las inscripciones de la mismidad (Romano-Sued, 1998). Concebida, entonces, como práctica creativa en sentido amplio, la traducción es también una vía de acceso a la comprensión de las complejas relaciones entre lengua, cultura, sociedad; una forma de introducir nuevas visiones en y sobre los géneros artísticos y las más existenciales cuestiones de género (Zaccaria, 2008).

Traducir es también focalizar lo extranjero, lo otro, en sus diferencias y en sus similitudes; es "comprender lo distinto, la necesidad de acercarse a la alteridad sin anularla» (Ricoeur, 2005: 14). La problematización de la mismidad y la otredad se radicalizan en la traducción y en el teatro, pues ambos son ejercicios de equivalencia, de semejanza, de invención; son, en última instancia, traiciones, falsificaciones, infidelidades, artificios de la lengua, del arte, de la escritura y de la cultura que, al pensar lo ajeno, imponen siempre, ineludiblemente, un regreso a nosotros mismos, una mirada sobre lo propio que nos revela y nos interpreta.

Si en palabras de George Steiner (1973) «Entender es traducir», equiparando traducción y teatro, podríamos decir entonces que «entender» es también «hacer y ver teatro». Ciertamente, si la traducción es un ejercicio semiótico y/o lingüístico, que refleja una ideología, una visión del mundo y, por lo tanto, se convierte en una vía de acceso a 
la realidad social, un paradigma explicativo de las complejas construcciones culturales (Vidal Claromonte, 1995; Isnardi, 1998), homologar traducción y práctica escénica nos permite entender desde otra perspectiva la función y necesidad del teatro en el marco de la cultura contemporánea, signada por la lógica que le imponen los medios masivos y su juego de infinitas mediaciones; nos ayuda a repensar aquello que conocemos a la luz de lo que tales mediaciones nos permiten conocer; nos recuerda básicamente los límites de nuestra condición humana, en la medida en que debemos renunciar al ideal de perfección y elaborar el duelo por la pérdida, por lo intraducible, por lo irrepresentable. Concebir la traducción como una clave hermenéutica para la crítica del teatro contemporáneo de impronta posmoderna, nos lleva, en última instancia, a repensar el discurso crítico en sí mismo y preguntarnos, como lo hacía Nicolás Rosa (2008) acerca de la práctica traductiva, si es una tarea intuitiva o puramente científica.

\section{A MODO DE CONCLUSIÓN}

Retomando nuestro punto de partida y, aun prescindiendo de un más profundo análisis del texto dramático y de su inscripción escénica, como así también de la discusión de las diferentes miradas críticas que recibiera el espectáculo de Catani-Pensotti (Cornago, 2007; Rud, 2007), hemos intentado destrabar las tautologías frecuentes en la crítica, referidas al señalamiento de lo real en la escena posdramática, señalamiento que suele operar como límite interpretativo, recurriendo a un marco teórico —en este caso concreto, la traducción - ajeno al fenómeno estético.

Para Artaud, la peste o la alquimia eran los dobles que permitían reflexionar acerca del teatro y, sobre todo, de la sociedad que lo genera y contiene. Del mismo modo, el teatro contemporáneo de impronta posdramática le propone a los críticos encontrar nuevos «dobles», nuevas claves de lectura capaces de mediar significativamente entre teatro y sociedad. Se trata desde luego de un arduo desafío, ya que, por un lado, tales dobles no serían universalizables ni necesariamente previstos en el proyecto creativo de cada espectáculo, sino puro efecto pragmático, pura construcción de la mirada crítica. Por otro lado, exigen del estudioso una enciclopedia aún más vasta, el manejo teórico de conocimientos no estrictamente teatrales y un adecuado dominio de diferentes discursos culturales.

Asimismo, la lectura crítica basada en estas nuevas «mediaciones» profundizaría el gesto político de la escena posdramática. No me refiero a lo "político» en términos meramente coyunturales o partidarios ni, menos aún, temáticos. Político en sentido amplio y complejo, en la medida en que el quehacer escénico argentino de algún modo colmó -y quizás aún colma-, vacíos y necesidades participativas, en especial los de la clase media (el sector más vinculado a lo teatral, como productor y como consumidor). Se trata, sin embargo, de una politicidad claramente diferenciable de la planteada por el teatro en décadas anteriores. En efecto, el llamado teatro político de los 70, que marcó la culminación y la declinación del proyecto de la modernidad teatral, estaba guiado por un propósito esencialmente didáctico, ya que en él se formulaban principios con pretensión de universalidad y se realizaba - directa o indirectamente- una exposición prescriptiva, referida a las reglas y a los comportamientos que debían seguirse en torno de temas 
250

vinculados a determinadas construcciones utópicas. Esto suponía la idea rectora de que la realidad existía fuera de la escena y, por lo tanto, era representable y modificable. Por el contrario, a través de una lectura crítica a partir de nuevos «dobles», de nuevas mediaciones interpretativas, los cuestionamientos metaescénicos posdramáticos ya no podrán considerarse un ademán narcisista, un estéril ejercicio de autorreferencialidad sobre la propia creación, sino, fundamentalmente, una eficaz estrategia política que, al plantear desde perspectivas inhabituales ideologemas sociales y culturales, nos permitan seguir reflexionando críticamente sobre nosotros mismos como comunidad y como individuos inmersos en los atribulados tiempos posmodernos.

\section{REFERENCIAS}

Blanchard, Jean-Marc. (1978). Of Cannibalism and Autobiography. Modern Languages Notes 4: 654-676. Vol. 93.

Cornago, Óscar. (2007). El teatro de Los muertos o los espacios de la ausencia. Beatriz Catani [Óscar Cornago (curador)], Acercamientos a lo real, textos y escenarios. Buenos Aires: Artes del Sur.

Darrieussecq, Marie. (1996). L'autofiction, un genre pas sérieux. Poétique 107: 369-379. Septiembre.

De Marinis, Marco. (1982). Semiótica del teatro. Milán: Bompiani.

Eco, Umberto. (1988) De los espejos y otros ensayos. Barcelona: Lumen.

Gómez Ramos, Antonio. (2000) Entre líneas. Gadamer y la pertenencia del traductor. Madrid: Visor.

Guzmán, María Constanza. (2008). Gregory Rabassa: el rostro de un traductor visible. En Patrizia Calefato y Pilar Godayol (coords.), Traducción/Género/Poscolonialismo. DeSignis 12: 167-174. Buenos Aires: La Crujía.

Isnardi, Graciela. (1998). Ideología y estética en al traducción literaria. Cuadernos Hispanoamericanos 576: 31-39. Junio.

Lehmann, Hasn-Thies. [1999] (2000). Le théâtre postdramatique. París: L 'Arche.

Lejeune, Philippe. (1973). Le pacte autobiographique. Poétique 14: 137-162. Abril.

Marías, Javier. (1993). La traducción como fingimiento y representación. Literatura y fantasma (pp. 195-203). Madrid: Ediciones Siruela.

Pavis, Patrice. (1991). Problemas de la traducción para la escena: interculturalismo y teatro posmoderno. En Hanna Scolnicov y Peter Holland (comp.), La obra de teatro fuera de contexto (39-62). México: Siglo XXI.

Reiss, Katharina y Hans J. Vermeer. (1996). Fundamentos para una teoría funcional de la traducción. Madrid: Akal.

Renza, Louis A. (1977). The Veto of the Imagination: A Theory of Autobiography. New Literary History 1: 1-26, vol. 9, otoño.

Ricoeur, Paul. (2005). Sobre la traducción. Buenos Aires: Paidós.

Robin Régine. (1993). L'autofiction. Le sujet toujours en défaut. En S. Durovsky, J. Lecarme y P. Lejeune (dir.), Autofictions \& Cie (pp. 73-86). Université Paris X, Centre de Recherches Interdisciplinaires sur les Textes Modernes.

Romano-Sued, Susana. (1998). Crítica y traducción. Babel en Babilonia. La escritura en 
la diáspora. Poéticas de traducción: significancia, sentido, reescritura (11-36). Córdoba: Narvaja Editor.

Rosa, Nicolás. (2008). Acerca de la traducción y de los traductores. En Patrizia Calefato y Pilar Godayol (coords.), Traducción/Género/Poscolonialismo. DeSignis 12: 191201. Buenos Aires: La Crujía.

Rud, Lucía. (2007). Ausencia y presencia: dublineses, berlineses y argentinos. En torno de Los muertos de Beatriz Catani y Mariano Pensotti. Telondefondo. Revista de Teoría y Crítica Teatral 2 (diciembre). Obtenido desde <www.telondefondo.org $>$.

Steiner, George. (1980). Después de Babel. Aspectos del lenguaje y la traducción. [1975]. México: Fondo de Cultura.

Taronnna Annamita. (2008). Examinar la teoría del género traduciendo la androginia. En Patrizia Calefato y Pilar Godayol (coords.), Traducción/Género/Poscolonialismo. DeSignis 12: 29-39. Buenos Aires: La Crujía.

Trastoy, Beatriz. (2002). Teatro autobiográfico. Los unipersonales de los 80 y 90 en la escena argentina. Buenos Aires: Nueva Generación.

VV. AA. (2006). Jornadas sobre la traducción literaria y filosófica. Ciclo de mesas redondas del Centro Cultural Rectos Ricardo Rojas de la Universidad de Buenos Aires, 12 al 15 de julio de 2005. Buenos Aires: Los Libros del Rojas.

Vidal Claramonte, María del Carmen África. (1995). Traducción, manipulación, desconstrucción. Salamanca: Ediciones Colegio de España.

Zaccaria, Paola. (2008). Traducir fronteras, poner en escena el transnacionalismo. En Patrizia Calefato y Pilar Godayol (coord.), Traducción/Género/Poscolonialismo. DeSignis 12: 75-84. Buenos Aires: La Crujía.

Recepción: marzo de 2009

Aceptación: junio de 2009 